\title{
Mathematical Problem Solving of ADHD Students: Which Interpretation to Prioritize?
}

\author{
${ }^{1}$ Thomas Rajotte, ${ }^{1}$ Lisa Bureau-Levasseur, ${ }^{2}$ Jacinthe Giroux, ${ }^{3}$ Dominic Voyer \\ ${ }^{1}$ Université du Québec en Abitibi-Témiscamingue \\ ${ }^{2}$ Université du Québec à Montréal \\ ${ }^{3}$ Université du Québec à Rimouski
}

\begin{abstract}
Research on learning difficulties in mathematics adopts one of two distinct perspectives. According to the first, learning difficulties are due to the intrinsic characteristics of the student. For supporters of the second perspective, those difficulties result from the interaction between the student and the school system. The objective of this study is to test the validity of these two perspectives in interpreting learning difficulties in mathematics among ADHD students. To this end, we collaborated with normally achieving (undiagnosed) and ADHD students. Results show that the second perspective is better suited to the interpretation of learning difficulties in mathematics of the ADHD students.
\end{abstract}

\section{Introduction}

Since the reform of the Quebec education system in 2000, the proper integration and the success of students with learning difficulties have become major issues for the Ministère de l'Éducation, du Loisir et des Sports [1]. These issues are the core orientation of the Politique en adaptation scolaire [2]. With regards to the prevention of learning difficulties, mathematics is one of the disciplines that deserve closer scrutiny. In fact, Deblois [3], argues that our mathematical knowledge is constantly solicited, in the daily tasks as well as in the professional duties we are called upon to perform.

The analysis of several research papers reveals two distinct positions on the issue of students with learning difficulties in mathematics. The first is mostly focused on the identification and the description of problems related to the student him or herself, while the second is more interested in the education system and the specific phenomena that define the relationships between the performance of the student, the effective teaching situation and the specificity of the knowledge being transmitted [4] [5]. Martin and Mary [6] support this position, adding that these two perspectives are at odds when it comes to explaining the specifics of mathematics as taught to students with difficulties.

These two perspectives are based on specific theoretical and methodological rationales and are supported by various (mostly academic) research sources. Moreover, they impact the way mathematics are being taught to a specific group of students and, by extension, they also impact the way this discipline is being learned by this same group of students [7].

To this end, scientific research that uses developmental psychology, neuropsychology and cognitive sciences in its explanatory framework is associated with the first perspective[8] [9]. Supporters of this perspective argue that learning difficulties are directly related to the student. In fact, they appear to be intrinsically linked to the functional and structural characteristics of the learner [10]. By adopting this point of view, the student is perceived as a subject whose personal attributes can be measured by standardized assessment tools. Also, still according to this perspective, the role of the teacher is to help the student make up for his/her difficulties via remedial interventions aimed at modifying his/her cognitive processes. In this context, the student is cast in the role of the person that requires help. Incidentally, some studies show that the assistance mechanisms put into place do not always stimulate the cognitive and mathematical engagement of the student [11]. In that respect, Roiné [12] mentions that difficulties in mathematics, as seen from this perspective, rest on the "specificity hypothesis", which states that teachers' interventions must be performed according to the classification of students into categories as performed in the school system.

Moreover, Lemoyne and Lessard [13] point out that in the last decades, research on learning difficulties using cognitive sciences in its explanatory framework has yielded very little empirical results. According to these authors, this has led to a challenge of the immutable nature of the cognitive characteristics of learners and an investigation of the way school functions as an institution. Consequently, a second rationale has been developed for learning difficulties. It is essentially based on the didactics of mathematics. In this perspective, learning difficulties are seen as the result of the interaction between the student and the school system in which he/she participates. In this context, the learner is considered as a student (therefore a subject of the didactic system) whose difficulties are caused at least in part by the didactic 
contract $^{1}$ binding him or her to the didactic system [14]. Therefore, according to Roiné [15], learning difficulties are, in this perspective, viewed through the lens of a "contract hypothesis".

This perspective considers teaching as the implementation of conditions that will encourage learning via didactic interventions that take into account the students' mathematical knowledge as well as the specificity of the knowledge being transmitted [16]. As for the students, they are modelled as active subjects who interact in a didactic environment developed by a teacher according to their cognitive dimensions and the characteristics of the knowledge to be learned [17].

In order to describe the perspective adopted by the various disciplines that study learning difficulties in mathematics, Giroux [18] developed a diagram that classifies these disciplines by finality or epistemological stance. This diagram, shown in Figure \#1, translates the finality of these disciplines on a lateral axis. A shift towards the left of this axis symbolizes a growing interest in the study of cognitive functions. This implies a focus on individual characteristics. Incidentally, Giroux [19] mentions that a shift towards the right end of the axis is the sign of a growing interest for the study of the way knowledge works in learning or teaching situations. This move involves a focus on the interactive phenomena required in the transmission and the acquisition of knowledge.

\begin{tabular}{|c|c|c|c|}
\hline \multicolumn{2}{|c|}{ COGNITIVE SCIENCES } & \multirow{2}{*}{$\begin{array}{l}\text { Developmental } \\
\text { psychology }\end{array}$} & \multirow{2}{*}{$\begin{array}{l}\text { Didactics of } \\
\text { mathematics }\end{array}$} \\
\hline Neuropsychology & $\begin{array}{l}\text { Cognitive } \\
\text { psychology }\end{array}$ & & \\
\hline $\begin{array}{l}\text { Study of the cerebral } \\
\text { seat of mental } \\
\text { functions }\end{array}$ & $\begin{array}{l}\text { Study of cognitive } \\
\text { processes } / \\
\text { formation of } \\
\text { knowledge }\end{array}$ & $\begin{array}{c}\text { Study of the child's } \\
\text { cognitive } \\
\text { development }\end{array}$ & $\begin{array}{l}\text { Study of mathematics } \\
\text { learning and teaching } \\
\text { conditions }\end{array}$ \\
\hline \multicolumn{4}{|c|}{$\longleftrightarrow$} \\
\hline \multicolumn{2}{|c|}{ Individuals caracteristics } & \multicolumn{2}{|c|}{$\begin{array}{l}\text { Interactions between } \\
\text { student/knowledge/schools' environnement }\end{array}$} \\
\hline
\end{tabular}

Figure 1. Organization of the disciplines that study difficulties in mathematics, according to Giroux [21]

Based on the findings of Giroux [22], it is possible to assume that supporters of the first perspective, which specifically includes research stemming from developmental psychology, neuropsychology and cognitive sciences, will be located on the left side of the diagram. This is justified by the explanatory framework for learning difficulties in mathematics, where the focus is on individual characteristics, which has been adopted by

\footnotetext{
1 According to Brousseau [20], the didactic contract allows the description of implicit or explicit rules governing the sharing of responsibilities in the transmission or the acquisition of knowledge between the teacher and the student. This contract is therefore a representation of the expectations of both parties.
}

researchers from these disciplines. On the opposite, supporters of the second perspective would be more specifically positioned on the right side of the diagram, as they are more focused on student interactions in a given didactic system.

\section{Departmental position on teaching mathematics to ADHD students}

The evolution of special education legislation and policies tends to align the position of the ministère de l'Éducation with the first perspective on ADHD students. This position is stated in the Politique en adaptation scolaire [23], developed to refocus the high-level guidelines of the education reform on special needs and the specifics of students with disabilities or adjustment or learning difficulties. This policy includes a ministerial directive to teachers, asking them to adapt their teaching to the needs and characteristics of their students [24] [25] [26].

Incidentally, it is appropriate to review the basis for the ministerial directive on the adaptation of teaching to the individual characteristics and needs of the students. To this end, Giroux [27] mentions that the position of the MELS is not based on the consideration of the didactic dimension of teaching and learning. In fact, the ministerial guidelines tend to implement teaching practices that constantly seek news ways to "bridge the gap" that separates ADHD students from the other students at the expense of the consideration of the specificity of the teaching contents and the didactic conditions that facilitate his/her learning. Also, even though the use of explanatory frameworks related to the didactics of mathematics is on the rise since the eighties [28], these ministerial directives, because of their explanatory position on learning difficulties, neglect, in a way, the results achieved by the didactics of mathematics.

\subsection{Research objectives}

All these considerations lead to a challenge of the interpretation conditions of learning difficulties in mathematics of ADHD students. In this research project, we will explore the validity of both perspectives on learning difficulties. To this end, we will assess whether the intrinsic characteristics of the students, as operationalized by the label "ADHD student", are a valid explanatory framework for learning difficulties in mathematics. The goal of this approach is to test the "specificity hypothesis". Moreover, to test the second interpretative perspective, we will explore the influence of the structure of statements of mathematical problems and the affiliation with a given school environment on the emergence of learning difficulties. This 
approach will be used specifically to test the "contract hypothesis".

\section{Methodology}

\subsection{Sample}

The sample that we assembled allowed us to conduct our experiment on 522 sixth-grade elementary students. A total of 67 ADHD students, as well as 455 undiagnosed students, took part in the research project. The participants came from 28 schools of the Québec area.

\subsection{Variables studied}

Several variables have been used in this research protocol. First, we considered the attribution of the "ADHD student" label to assess whether individual characteristics influenced the efficiency of problemsolving procedures used. The efficiency of the procedures used by ADHD students is compared with those of undiagnosed students. Then, to explore the influence of the adhesion to a specific learning community, we considered the class to which each student belonged.

\subsection{Difficulties in mathematics}

In order to document the difficulties in mathematics encountered by ADHD students, we studied the relational calculus used to solve mathematical problems. More specifically, we analyzed the relational calculus developed in nine distinct problems on proportions. The problems varied according to the type of information presented: problems providing only the data essential to the resolution of the problem, problems providing situational elements of information, and statements providing superfluous elements of information. Also, our problem statements on proportions included three distinct types of numerical relationships: integer within relationship, integer between relationship, as well as noninteger relationship. The characteristics of the nine problems that we used in our study are presented in Table 1.

Table 1. Presentation of the structure of the nine problem statements

\begin{tabular}{|c|c|c|c|}
\hline & Essential data & $\begin{array}{c}\text { Situational } \\
\text { elements }\end{array}$ & $\begin{array}{c}\text { Superfluous } \\
\text { elements }\end{array}$ \\
\hline $\begin{array}{c}\text { Integer within } \\
\text { relationship }\end{array}$ & Problem \#5 & Problem \#2 & Problem \#6 \\
\hline $\begin{array}{c}\text { Integer between } \\
\text { relationship }\end{array}$ & Problem \#4 & Problem \#1 & Problem \#7 \\
\hline $\begin{array}{c}\text { Noninteger } \\
\text { relationship }\end{array}$ & Problem \#9 & Problem \#8 & Problem \#3 \\
\hline
\end{tabular}

\subsection{Statistical analysis}

To meet our research objectives, we implemented three distinct statistical tests. First, to compare the efficiency of problem-solving procedures of ADHD and undiagnosed students, we performed chi-squared analyses for each of the nine problems. Then, to compare the level of difficulty implied by the structure of the problem statements, we performed paired t-tests for each problem pair. Finally, we performed an analysis of variance (ANOVA) and an analysis of covariance (ANCOVA) to explore the influence of the affiliation to a specific learning community. The goal of this analysis was to verify the existence of differences of performance in problem resolution between the various sixth grade classes with which we collaborated.

\section{Results}

\subsection{Comparison of the relational calculus of ADHD and undiagnosed students}

To meet our first research objective, which is the comparison of the relational calculus of ADHD and undiagnosed students, we performed a chi-squared test for each of the problem statements. The results of the chi-squared tests are presented in Table 2. These analyses showed significant differences in the problem-solving procedures used in problems \#2 (chi-squared $=16.730 ; \mathrm{p} \square 0.001$ ).

\subsection{Comparison of the level of difficulty of the problems}

To meet our second research objective, we compared the levels of difficulty of each of the mathematical problems. To this end, we performed a paired t-test for the various possible combinations of problem pairs. We conducted a total of 36 distinct paired t-tests, since there were 36 possible combinations. To address the inflation of the alpha, we performed the Bonferroni correction by dividing our level of significance by 36 for each of these tests. Consequently, our level of significance for each paired t-test was set to $\mathrm{p} \leq 0.001(0.05 / 36)$.

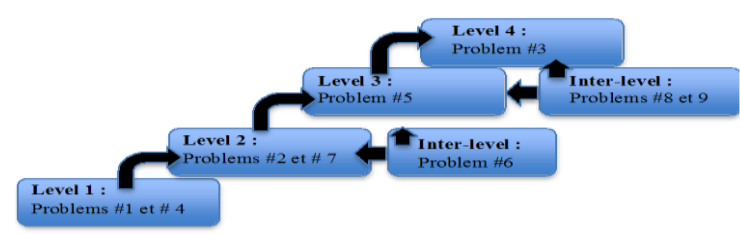

Figure 2. Prioritization of the level of difficulty of each problem statement

Table 2. Comparison of the relational calculus of ADHD students and undiagnosed students 


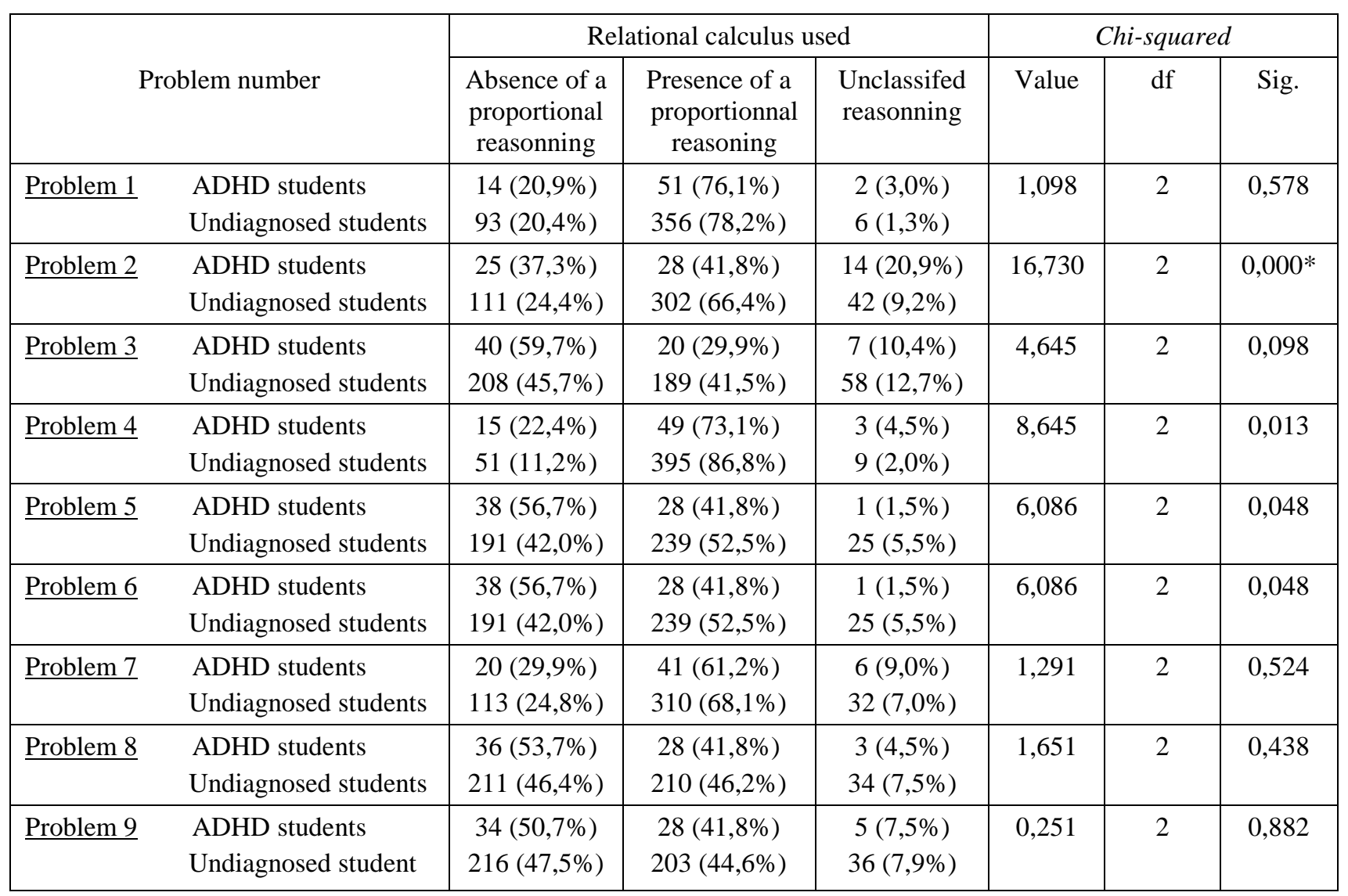

Conducting these tests allowed us to conclude that out of the 36 pairs of problems, 26 involved diverging levels of difficulty. These results show that statistically significant differences exist in terms of the difficulty involved in the majority of the problems selected in our research protocol. The prioritization of the levels of difficulty based on the structure of the problems is depicted in Figure 2. Moreover, the ordering of didactical variables according to their level of complexity is shown in Table 3.

\subsection{Exploration of the impact of belonging to a class}

Finally, we verified if belonging to a class supervised by a specific homeroom teacher had any impact on the resolution of problems on proportions. To this end, we performed an analysis of variance (ANOVA). Also, to meet the conditions of application of ANOVA, we assessed the homogeneity of the data by performing Levene's test. Results of those tests are shown in Tables 3 and 4.

Table 3. Ordering of didactical variables according to their level of complexity

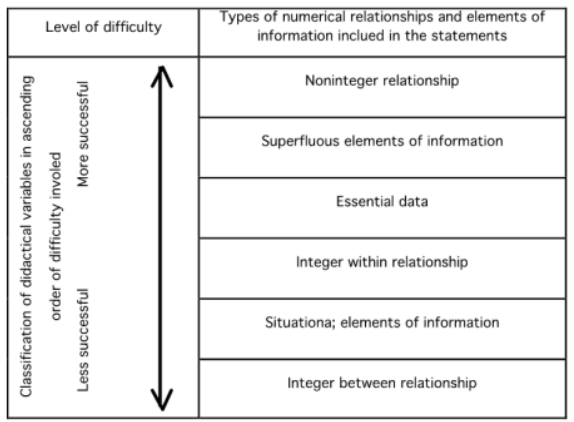

Based on the data yielded by our ANOVA, we can conclude that the performance of the students in problem-solving was influenced by the sixth-grade class to which they belonged $(F=3.999 ; \mathrm{p}<0.001)$. Also, Cohen [29] states that the portion of the variance in problem-solving explained by the school environment is quite significant $(\eta 2=0,168)$. A subsequent analysis of covariance (ANCOVA) revealed that these class-based differences in performance are important $(\mathrm{F}=2,882 ; \mathrm{p}<0.001 ; \eta 2$ $=0,118)$ even when the students' socioeconomic environment is controlled. The results of the ANCOVA are presented in Table 5.

Table 4. Results of Levene's test 


\begin{tabular}{|l|c|c|c|c|}
\hline $\begin{array}{l}\text { Dependant } \\
\text { variables }\end{array}$ & $\begin{array}{l}\text { Levene's } \\
\text { statistics }\end{array}$ & Df1 & Df2 & Sig. \\
\hline Total Results & 1,085 & 25 & 496 & 0,356 \\
\hline
\end{tabular}

Table 5. Results for the ANOVA for the success rate in problem solving as obtained by every class

\begin{tabular}{|l|l|c|c|c|c|c|c|}
\hline \multicolumn{2}{|l|}{} & $\begin{array}{c}\text { Sum of } \\
\text { squares }\end{array}$ & df & $\begin{array}{c}\text { Mean } \\
\text { square }\end{array}$ & F & Sig. & $\begin{array}{c}\text { Effect } \\
\text { size }\end{array}$ \\
\hline Total & Between groups & 8276 & 25 & 331,04 & 3,99 & 0,00 & 0,168 \\
Results & Within groups & 41056 & 496 & 82,77 & & & \\
& Total & 49332 & 521 & & & & \\
\hline
\end{tabular}

Table 6. Results for the ANCOVA for the success rate in problem solving on proportions as obtained by every class

\begin{tabular}{|l|l|c|c|c|c|c|c|}
\hline \multicolumn{2}{|l|}{} & $\begin{array}{c}\text { Sum of } \\
\text { squares }\end{array}$ & df & $\begin{array}{c}\text { Mean } \\
\text { square }\end{array}$ & F & Sig. & $\begin{array}{c}\text { Effect } \\
\text { size }\end{array}$ \\
\hline Total & Between groups & 5487 & 23 & 238,59 & 2,88 & 0,00 & 0,118 \\
Results & Within groups & 41056 & 496 & 82,77 & & & \\
& Total & 497957 & 522 & & & & \\
& Corrected total & 49332 & 521 & & & & \\
\hline
\end{tabular}

\section{Data interpretation}

We think that the results of this research project tend to confirm that the "contract hypothesis" is the most appropriate interpretative perspective to explain the learning difficulties in mathematics experienced by ADHD students. This conclusion is reached because the characteristics of the students, operationalized by the use of the "ADHD student" label, have little influence over the efficiency of the relational calculus used to solve the problems on proportions. In only one problem out of nine did the undiagnosed students use more efficient procedures than ADHD students. This conclusion challenges the validity of the "specificity hypothesis", because demonstrating that the nature of the procedures used by the various categories of students did not differ implies that teachers do not need to adapt their interventions to the characteristics of their students.

We have demonstrated that the structure of the problems and the student's belonging to a school environment have significant impact on his/her performance. These results support the "contract hypothesis" by arguing that various didactic considerations influence the relational calculus of sixth-grade students. Consequently, we suggest that the difficulties in solving problems on proportions experienced by students be interpreted based on their interactions with the school system in which they operate and the specificity of the knowledge involved. Our results challenge the very basis of the ministerial directives that recommend educators take action according to the psychological characteristics of the students.

Further research in didactics of mathematics is required to better understand the teaching of proportional reasoning to ADHD students. Thus, we suggest the exploration of the various didactic phenomena likely to happen in a class where inclusive education is encouraged. To this end, we propose to document didactic phenomena that occur with children characterised with a specific label.

\section{References}

[1] Squalli, H.; Venet, M. et Lessard, A. (2006). Intervention auprès de l'élève à risque : approches multiples et différenciées. Nouveaux cahiers de la recherche en éducation, 9(2), 119-122.

[2] Gouvernement du Québec (1999). Une école adaptée à tous les élèves. Politique de l'adaptation scolaire. Québec : Ministère de l'Éducation du Québec.

[3] Deblois, L. (2011). Enseigner les mathématiques : des intentions à préciser pour planifier, guider et interpréter. Presses de l'Université Laval : Sainte-Foy.

[4] Giroux, J. (2010). Pour une différenciation de la dyscalculie et des difficultés d'apprentissage en mathématiques. Actes de colloque du GDM: Moncton.

[5] Roiné, C. (2009). Cécité didactique et discours noosphériens dans les pratiques d'enseignement en S.E.G.P.A : Une contribution à la question des inégalités. Thèse inédite. Université Victor Segalen Bordeaux 2 : Bordeaux.

[6] Martin, V. et Mary (2010). Particularités de l'enseignement des mathématiques à des élèves en difficulté en classes régulières ou spéciales. Actes du colloque du GDM. Université de Moncton : Moncton.

[7] Martin, V. et Mary (2010). Op cit. p. 229-240.

[8] Giroux, J. (2010). Op cit. p. 148-159.

[9] Martin, V. et Mary (2010). Op cit. p.229-235.

[10] Lemoyne, G. et Lessard, G. (2003). Les rencontres singulières entre les élèves présentant des difficultés d'apprentissage en mathématiques et leurs enseignants. Éducation et francophonie, 21(2). [En ligne]. Disponible le 30 septembre 2011:http://www.acelf.ca/revue/ revuehtml/31-2/01-lemoyne.html.

[11] Martin, V. et Mary (2010). Op cit. p. 230-233.

[12] Roiné, C. (2009). Op cit. p.238-240.

[13] Lemoyne, G. et Lessard, G. (2003). Op cit. p.13-30.

[14] Perrin-Glorian, M.-J. (1993). Questions didactiques soulevées à partir de l'enseignement des mathématiques dans des classes "faibles ». Recherche en didactique des mathématiques, 13(1/2), 5-18.

[15] Roiné, C. (2009). Op cit. p.238-240.

[16] Martin, V. et Mary (2010). Op cit. p.229-240.

[17] Mary, C.; Squalli, H. et Schmidt, S. (2008). Mathématiques et élèves en difficulté grave d'apprentissage: Contexte favorable à l'intégration et au raisonnement mathématique. Dans J.M. Bisaillon et N. Rousseau (Éds.). Les jeunes en difficulté: Contextes d'intervention favorables. Presses de l'Université du Québec: Québec.

[18] Giroux, J. (2010). Op cit. p. 148-159.

[19] Giroux, J. (2010). Op cit. p. 148-159.

[20] Brousseau, G. et Balacheff, N. (1998). Théorie des situations didactiques: didactique des mathématiques 1970-1990. Grenoble: La Pensée Sauvage.

[21] Giroux, J. (2010). Op cit. p.148-159

[22] Giroux, J. (2010). Op cit. p. 150-154

[23] Gouvernement du Québec (1999). Une école adaptée à tous les élèves. Politique de l'adaptation scolaire. Québec : Ministère de l'Éducation du Québec. 
[24] Gouvernement du Québec (1999). Op cit. p.11-16.

[25] Gouvernement du Québec (2006). L'évaluation des apprentissages au secondaire, Cadre de référence. Québec : Ministère de l'Éducation, du Loisir et du Sport.

[26] Ministère de 1'Éducation du Québec. (2000). Trouble de déficit de l'attention/hyperactivité : rapport du comitéconseil sur le trouble de déficit de l'attention/hyperactivité et sur l'usage de stimulants du système nerveux central. Québec, Gouvernement du Québec.

[27] Giroux J. (2007) - «Adapter l'enseignement en classe d'adaptation scolaire (La TSD à la rescousse des difficultés d'enseignement aux élèves en difficulté d'apprentissage), Entre didactique et politique : Actualités de la Théorie des Situations Didactiques à propos de quelques questions vives sur l'enseignement des mathématiques à l'école élémentaire, Contribution au Symposium Bordeaux 2, mai 2007.

[28] Lemoyne, G. et Lessard, G. (2003), op cit. p.13-25

[29] Cohen, J. (1988). Statistical power analysis for the behavioral sciences. Hillsdale : Lawrence Erlbaum. 